\title{
ESTABELECIMENTO IN VITRO DE MIRTILO A PARTIR DE SEGMENTOS NODAIS
}

\section{IN VITRO ESTABLISHMENT OF BLUEBERRY TREES STARTING FROM NODAL SEGMENTS}

\author{
Alan Cristiano ERIG ${ }^{1}$ \\ Márcia Wulff $\mathrm{SCHUCH}^{2}$
}

\begin{abstract}
RESUMO
Com o objetivo de definir a constituição do meio de cultura, o comprimento do explante e o estado físico do meio de cultura que favoreçam o estabelecimento in vitro de mirtilo, cvs. Flórida e Delite, dois experimentos foram realizados. No experimento I, onde segmentos nodais da cv. Flórida foram utilizados como explantes, estudou-se quatro diferentes constituições do meio de cultura WPM (T1: WPM - testemunha; T2: WPM + 24,6 $\mu \mathrm{M}$ de 2iP; T3: WPM + 24,6 $\mu \mathrm{M}$ de $2 \mathrm{iP}+2,68 \mu \mathrm{M}$ de ANA; e, T4: WPM + 24,6 $\mu \mathrm{M}$ de $2 \mathrm{PP}$ $+2,68 \mu \mathrm{M}$ de $\mathrm{ANA}+1,44 \mu \mathrm{M}$ de $\mathrm{AG}_{3}$ ). Os meios de cultura com as vitaminas de Gamborg, foram adicionados de mio-inositol (100 $\left.\mathrm{mg} \cdot \mathrm{L}^{-1}\right)$, sacarose $\left(30 \mathrm{~g} \cdot \mathrm{L}^{-1}\right)$ e ágar $\left(6 \mathrm{~g} \cdot \mathrm{L}^{-1}\right)$. No experimento II, com material vegetal da cv. Delite, foram estudados dois estados físicos do meio de cultura (semi-sólido e líquido) e três comprimentos dos explantes - segmentos nodais $(0,5 ; 1 \mathrm{e} 1,5 \mathrm{~cm})$. Neste experimento, o meio de cultura WPM com as vitaminas de Gamborg foi acrescido de 2iP $(24,6 \mu \mathrm{M})$, mio-inositol (100 mg.L-1) e sacarose (30 g.L-1). Ao meio semi-sólido adicionou-se ágar ( 6 g.L-1 $)$, e no meio líquido, chumaços de algodão sustentaram os explantes. No experimento I, o meio de cultura WPM $+24,6 \mu \mathrm{M}$ de 2iP propiciou a maior percentagem de estabelecimento (70,74\%). No experimento II, o comprimento do explante não teve efeito sobre o estabelecimento. Em relação ao estado físico do meio de cultura, a percentagem de estabelecimento foi superior utilizando-se o meio semi-sólido (79,23\%), comparado ao meio líquido (0,74\%).
\end{abstract}

Palavras-chave: cultura de tecidos, WPM, meio de cultura, 2iP, pequenas frutas.

\begin{abstract}
With the objective of defining the culture medium constitution, the explant length and the physical state of culture medium to favor the in vitro establishment of blueberry, cvs. Flórida and Delite, were accomplished two experiments. In the experiment I, where nodal segments of the cv. Flórida were used as explants, it was studied four different constitutions of the WPM culture medium (T1: WPM - testimony; T2: WPM + 24.6 $\mu \mathrm{M}$ 2iP; T3: WPM + 24.6 $\mu \mathrm{M} 2 \mathrm{iP}+2.68 \mu \mathrm{M} \mathrm{NAA}$; and, T4: WPM + $24.6 \mu \mathrm{M} 2 \mathrm{iP}+2.68 \mu \mathrm{M}$ NAA + $\left.1.44 \mu \mathrm{M} \mathrm{GA}_{3}\right)$. The culture mediuns with Gamborg vitamins, were added of myo-inositol (100 mg.L-1), sucrose $\left(30 \mathrm{~g} \cdot \mathrm{L}^{-1}\right)$ and agar $\left(6 \mathrm{~g} . \mathrm{L}^{-}\right.$ 1). In the experiment II, with vegetable material of the cv. Delite, were studied two physical states of the culture medium (semi-solid and liquid) and three explants lengths - nodal segments $(0.5 ; 1$ and $1.5 \mathrm{~cm})$. In this experiment, the WPM culture medium with Gamborg vitamins was added of $2 \mathrm{iP}(24.6 \mu \mathrm{M})$, myo-inositol $\left(100{\left.\mathrm{mg} . \mathrm{L}^{-1}\right)}^{-}\right.$and sucrose $\left(30 \mathrm{g.L} \mathrm{L}^{-1}\right)$. To the semi-solid medium agar was added $(6$ g. $\mathrm{L}^{-1}$ ), and in the liquid medium, cotton wads sustained the explants. In the experiment I, the WPM culture medium $+24.6 \mu \mathrm{M} 2 \mathrm{iP}$ propitiated the higher establishment percentage $(70.74 \%)$. In the experiment II, the length of the explant did not have effect on establishment. In relation to the physical state of the culture medium, the establishment percentage was higher being used the semi-solid medium (79.23\%), compared to the liquid medium (0.74\%).
\end{abstract}

Key-words: tissue culture, WPM, culture medium, 2iP, small fruits.

\footnotetext{
${ }^{1}$ Engenheiro Agrônomo, Dr., Pesquisador Bolsista de Pós-Doutorado do Conselho Nacional de Desenvolvimento Científico e Tecnológico (CNPq), Laboratório de Micropropagação de Plantas Frutíferas, Departamento de Fitotecnia, Faculdade de Agronomia Eliseu Maciel (FAEM) / Universidade Federal de Pelotas (UFPel). Caixa Postal 354, CEP 96.010-900, Pelotas, RS. E-mail: acerig@ufpel.tche.br Autor para correspondência; ${ }^{2}$ Engenheira Agrônoma, Dra., Professora do Departamento de Fitotecnia, Faculdade de Agronomia Eliseu Maciel (FAEM) / Universidade Federal de Pelotas (UFPel). Caixa Postal 354, CEP 96.010-900, Pelotas, RS. E-mail: marciaws@ufpel.tche.br.
} 


\section{INTRODUÇÃO}

O mirtilo ('blueberry' ou 'arándano') pertencente à família das Ericáceas e ao gênero Vaccinium, é uma fruta de clima temperado que apresenta grande importância comercial, especialmente nos Estados Unidos e em alguns países da Europa [19]. Suas perspectivas de cultivo com sucesso são bastante animadoras nos países do hemisfério Sul, especialmente, devido à época de colheita coincidir com a plena entressafra dos países maiores produtores e, ao mesmo tempo, maiores consumidores [21]. Além disto, existe um mercado capaz de absorver 250.000 toneladas anuais de mirtilo, como é o caso dos Estados Unidos. Este mercado, de mais de 270 milhões de habitantes, possui fortemente arraigada em seus costumes o consumo desta fruta [17].

A região sul do Brasil tem grande potencial para a produção de pequenas frutas, destacando-se o mirtilo (Vaccinium ashei) [23]. Esta espécie apresenta alta rentabilidade, devido à baixa utilização de insumos e, até o momento, facilidade de produção limpa, resguardando o ambiente e a segurança alimentar [22]. No entanto, no Brasil, as áreas de cultivo de mirtilo ainda são incipientes, estima-se que sejam em torno de 20 hectares, estando restritas ao Rio Grande do Sul e a regiões serranas de Minas Gerais. A falta de um método eficiente de propagação tem dificultado a expansão desta cultura, visto que os viveiristas não dispõem de mudas de mirtilo para a comercialização [4].

A propagação do mirtilo pode ser realizada por sementes, rebentos e estacas. A propagação por sementes é útil no desenvolvimento de novas variedades, mas induz um longo período improdutivo e produz plantas diferentes da planta-matriz em muitas características. O uso de rebentos permite a obtenção de mudas grandes e em curto período de tempo, porém, em pequeno número [6]. Comercialmente, a produção de mudas é feita através de estaquia, mas os resultados práticos muitas vezes são insatisfatórios e variáveis com a cultivar $[15 ; 6]$.

A micropropagação constitui-se num método de produção de mudas que apresenta várias vantagens, e é a modalidade, dentro da cultura de tecidos, que mais se tem difundido e, segundo Grattapaglia e Machado [9] encontrado aplicações práticas. No Uruguai, em resposta a crescente demanda de mudas de mirtilo por parte de viveiristas e produtores, a micropropagação tem sido difundida como um método eficiente de propagação de variedades de mirtilo em escala comercial, através de um sistema desenvolvido e patenteado pelo INIA'Instituto Nacional de Investigación Agropecuaria' [2]. Segundo estes autores, a micropropagação permite a obtenção de uma grande quantidade de plantas utilizando pequena quantidade de material vegetal original, restringindo ou minimizando a limitação que a baixa oferta de mudas de mirtilo constitui para a expansão desta cultura. Enquanto isso, no Brasil, as pesquisas com esta espécie ainda são incipientes [3].
Na micropropagação de uma espécie, a primeira etapa é o estabelecimento in vitro de plantas, o que se inicia com a seleção dos explantes mais adequados para a micropropagação e termina com a obtenção de uma cultura livre de contaminantes visíveis e, suficientemente, adaptada às condições in vitro, de modo que apresente reação à aplicação de fitorreguladores na fase seguinte de multiplicação [9].

O objetivo deste trabalho foi definir a constituição do meio de cultura, o comprimento de segmentos nodais e o estado físico do meio de cultura que favoreçam o estabelecimento in vitro de mirtilo (Vaccinium ashei Reade), cvs. Flórida e Delite, para início da micropropagação.

\section{METODOLOGIA}

Os dois experimentos que compõem este trabalho foram realizados no Laboratório de Micropropagação de Plantas Frutíferas, do Departamento de Fitotecnia da Faculdade de Agronomia Eliseu Maciel (FAEM), na Universidade Federal de Pelotas (UFPel), em Pelotas, RS.

No experimento I, os tratamentos aplicados foram quatro diferentes constituições de fitorreguladores de crescimento adicionadas ao meio de cultura WPM - 'Wood Plant Media' [14] (T1: WPM - testemunha; T2: WPM + 24,6 $\mu \mathrm{M}$ de $2 \mathrm{iP}\left[\mathrm{N}^{6}-\right.$ isopenteniladenina]; T3: WPM + 24,6 $\mu \mathrm{M}$ de $2 \mathrm{iP}+$ 2,68 $\mu \mathrm{M}$ de ANA [ácido naftalenoacético]; e, T4: WPM $+24,6 \mu \mathrm{M}$ de $2 \mathrm{iP}+2,68 \mu \mathrm{M}$ de ANA + 1,44 $\mu \mathrm{M}$ de $\mathrm{AG}_{3}$ [ácido giberélico]), no delineamento experimental inteiramente casualizado, com cinco repetições por tratamento. Cada repetição constituiu-se por seis tubos de ensaio com um explante cada. Os segmentos nodais, com uma gema e comprimento aproximado de $1 \mathrm{~cm}$, utilizados como explantes, foram obtidos de brotações novas de mudas de mirtilo da cv. Flórida mantidas em vasos na casa de vegetação. $O$ meio de cultura WPM com as vitaminas de Gamborg et al. [7] foi acrescido de $100 \mathrm{mg} . \mathrm{L}^{-1}$ de mio-inositol, $30 \mathrm{~g} . \mathrm{L}^{-1}$ de sacarose, e adicionado ou não de fitorreguladores de crescimento conforme o tratamento. $\mathrm{O} \mathrm{pH}$ foi ajustado para 4,8 antes da inclusão do ágar na concentração de $6 \mathrm{~g} . \mathrm{L}^{-1} \mathrm{e}$, posteriormente, foi autoclavado a $121^{\circ} \mathrm{C}$ e $1,5 \mathrm{~atm}$ por 20 minutos. Nos dois experimentos foram utilizados tubos de ensaio $(150 \times 20 \mathrm{~mm})$ com $10 \mathrm{~mL}$ de meio de cultura.

No experimento II, foram testados dois estados físicos do meio de cultura (semi-sólido e líquido) e três comprimentos dos explantes $(0,5 ; 1$ e $1,5 \mathrm{~cm})$, no delineamento experimental inteiramente casualizado, em esquema fatorial $2 \times 3$, com cinco repetições por tratamento. Cada repetição constituiu-se por seis tubos de ensaio com um explante cada. Segmentos nodais com uma gema e comprimento conforme o tratamento, provenientes de brotações novas de 
mudas de mirtilo da cv. Delite mantidas em vasos na casa de vegetação foram utilizados como explantes.

Neste experimento, utilizou-se o meio de cultura WPM com as vitaminas de Gamborg et al. [7] adicionado de 24,6 $\mathrm{MM}$ de 2iP, $100 \mathrm{mg} \cdot \mathrm{L}^{-1}$ de mioinositol, $30 \mathrm{~g} . \mathrm{L}^{-1}$ de sacarose. $\mathrm{O} \mathrm{pH}$ foi ajustado para 4,8 e, posteriormente, foi autoclavado a $121^{\circ} \mathrm{C}$ e 1,5 atm por 20 minutos. Ao meio semi-sólido adicionouse ágar na concentração de $6 \mathrm{~g} \cdot \mathrm{L}^{-1}$ antes da autoclavagem. Para o meio líquido utilizou-se um chumaço de algodão no tubo de ensaio, para sustentação do explante.

As mudas doadoras de explantes nos dois experimentos, mantidas em vasos na casa de vegetação, foram pulverizadas semanalmente até 45 dias antes da coleta das brotações, com o antibiótico agrimicina (oxitetraciclina e sulfato estreptomicina), e os fungicidas cercobin (tiofanato-metílico) e kumulus (enxofre), nas doses de 2,4 g.L. respectivamente, visando diminuir a contaminação in vitro. As brotações novas coletadas foram levadas ao laboratório, onde inicialmente sofreram uma toalete, eliminando-se as folhas na altura do pecíolo, e cortando-as em segmentos caulinares com quatro a seis gemas, sendo, em seguida, desinfestadas. A desinfestação, realizada em câmara de fluxo laminar, constituiu-se primeiramente da imersão do material vegetal em álcool a $70 \%$ durante 15 segundos, seguido de hipoclorito de sódio com $2-2,5 \%$ de cloro ativo (água sanitária comercial) durante 5 minutos, adicionando-se uma gota de Tween 20. Na seqüência, o material vegetal foi lavado três vezes com água destilada e autoclavada, para posterior isolamento dos explantes.

Após a inoculação, os tubos de ensaio contendo os explantes foram mantidos no escuro, a $25 \pm 2^{\circ} \mathrm{C}$, por um período de sete dias, visando evitar ou minimizar a oxidação fenólica. Em seguida, foram transferidos para sala de crescimento com 16 horas de fotoperíodo, temperatura de $25 \pm 2^{\circ} \mathrm{C}$ e densidade de fluxo de fótons do período de luz de $42 \mu \mathrm{mol} \cdot \mathrm{m}^{-2} \cdot \mathrm{s}^{-1}$.

Aos 21 dias de cultivo foram avaliadas a percentagem de contaminação bacteriana, percentagem de contaminação fúngica e percentagem de oxidação, e os frascos que apresentaram contaminação ou oxidação, após registro, foram eliminados. Aos 35 dias de cultivo avaliou-se a percentagem de sobrevivência e a percentagem de estabelecimento. A sobrevivência foi indicada pela coloração verde do explante e o estabelecimento pela emissão de folhas ou broto a partir do explante. Os dados foram submetidos à análise de variância e as médias dos tratamentos comparadas estatisticamente pelo teste de Duncan em nível de $5 \%$ de probabilidade de erro, através do uso do SANEST [26]. Os dados em percentagem foram transformados em arco seno da raiz quadrada de $x / 100$, onde $x$ é o percentual obtido.

\section{RESULTADOS E DISCUSSÃO}

\section{Experimento I}

A contaminação e a oxidação dos explantes não representaram entraves ao estabelecimento in vitro de mirtilo cv. Flórida. A contaminação bacteriana e a oxidação foram nulas, e a contaminação fúngica ocorreu, em média, em apenas 1,36\% dos explantes. Estes resultados, provavelmente, se devem à manutenção das plantas-matrizes em ambiente limpo e protegido (casa de vegetação) e à pulverização prévia das mesmas com antibiótico e fungicidas, e reforçam a afirmativa de Montarroyos [16], de que a condição fitossanitária da planta-matriz determina o grau de facilidade do processo de eliminação de microrganismos contaminantes existentes no explante, durante a sua introdução in vitro. Segundo Jaakola et al. [11], a iniciação do cultivo in vitro de explantes de Vaccinium geralmente é limitada pela contaminação, especialmente quando o material vegetal é proveniente de plantas-matrizes mantidas no campo. Gonzales et al. [8] verificaram que a percentagem de contaminação e de necrose (oxidação) foi de $50 \%$ e $8 \%$, respectivamente, no estabelecimento in vitro de mirtilo cv. Berkeley usando segmentos nodais de brotações de plantas-matrizes mantidas no campo. No estabelecimento in vitro de mirtilo cvs. Blue Belle e Delite, Silva et al. [24] também observaram maior percentagem de oxidação nos explantes provenientes de material vegetal do campo (12\%), comparado aos explantes isolados de plantas da casa de vegetação $(0,08 \%)$.

Para a sobrevivência dos explantes (indicada pela coloração verde do explante) obteve-se uma média de $88,64 \%$ aos 35 dias de cultivo in vitro, independentemente da constituição de fitorreguladores de crescimento adicionada ao meio de cultura. Gonzales et al. [8], obtiveram $42 \%$ de sobrevivência dos explantes no estabelecimento in vitro de mirtilo cv. Berkeley a partir de segmentos nodais, utilizando o meio de cultura WPM com as vitaminas de MS [18]. Segundo Erig e Schuch [5], a alta percentagem de sobrevivência de explantes nem sempre pode ser usado como indicativo de que haverá o estabelecimento de plantas a partir destes explantes. Muitas vezes os tecidos dos explantes continuam vivos (de coloração verde), no entanto, não emitem folhas ou brotos, isto é, não se estabelecem in vitro, o que pode ser justificado pelo grau de desenvolvimento da gema do explante.

Neste experimento, a alta percentagem de sobrevivência (88,64\%) também deu lugar a uma alta percentagem de estabelecimento $(70,74 \%)$ com o meio de cultura WPM acrescido de $24,6 \mu \mathrm{M}$ de $2 \mathrm{iP}$ (Tabela 1). Nesta situação, apenas $17,9 \%$ dos explantes que sobreviveram não se estabeleceram in vitro, isto é, não emitiram folhas ou broto. Estes resultados estão de acordo com Jaakola et al. [11], onde a maior percentagem de estabelecimento in vitro de segmentos nodais de Vaccinium vitis-idaea, 
ERIG, A.C. e SCHUCH, M.W. Estabelecimento in vitro de mirtilo...

aproximadamente $18 \%$, também foi obtida com 24,6 $\mu \mathrm{M}$ de $2 \mathrm{iP}$ no meio de cultura. Resultados semelhantes foram observados por Gonzales et al. [8], na multiplicação in vitro de mirtilo cv. Berkeley, onde o maior número de brotações por explante foi obtido com a adição de $25 \mu \mathrm{M}$ de $2 \mathrm{iP}$ ou $18 \mu \mathrm{M}$ de zeatina ao meio de cultura WPM.

TABELA 1 - Percentagem de estabelecimento de explantes (segmentos nodais) de mirtilo cv. Flórida, aos 35 dias de cultivo in vitro, em função da constituição de fitorreguladores de crescimento adicionados ao meio de cultura WPM - 'Wood Plant Media' (Lloyd e McCown, 1980). UFPel, Pelotas, RS. 2005.

\begin{tabular}{lc}
\hline \multicolumn{1}{c}{ Meio de cultura } & \% de estabelecimento* \\
\hline T1: WPM - testemunha & $42,26 a b$ \\
T2: WPM + 24,6 $\mu \mathrm{M}$ de 2iP & $70,74 \mathrm{a}$ \\
T3: WPM $+24,6 \mu \mathrm{M}$ de 2iP $+2,68 \mu \mathrm{M}$ de ANA & $43,21 \mathrm{ab}$ \\
T4: WPM $+24,6 \mu \mathrm{M}$ de $2 \mathrm{iP}+2,68 \mu \mathrm{M}$ de ANA $+1,44 \mu \mathrm{M}$ de $\mathrm{AG}_{3}$ & $18,8 \mathrm{~b}$ \\
\hline Média & 43,75 \\
CV $(\%)$ & 30,49 \\
\hline
\end{tabular}

*Médias não seguidas pelas mesmas letras diferem pelo teste de Duncan em nível de $5 \%$ de probabilidade de erro.

A ausência de $2 \mathrm{iP}$ no meio de cultura (testemunha) e a presença de $2 \mathrm{iP}+\mathrm{ANA}$ não diferiram estatisticamente do meio de cultura adicionado apenas de $2 \mathrm{iP}$, obtendo-se $42,26 \%$, $43,21 \%$ e $70,74 \%$ de estabelecimento, respectivamente (Tabela 1). A adição de $2 \mathrm{iP}+\mathrm{ANA}$ $+\mathrm{AG}_{3}$ ao meio de cultura proporcionou uma percentagem de estabelecimento de apenas $18,8 \%$. $\mathrm{Na}$ multiplicação in vitro de mirtilo cv. Berkeley, Gonzales et al. [8] obtiveram o pior resultado com $2 \mathrm{iP}(25 \mu \mathrm{M})+\mathrm{AIA}(3 \mu \mathrm{M})+\mathrm{AG}_{3}(1,5 \mu \mathrm{M})$ no meio de cultura. Segundo Grattapaglia e Machado [9], a adição de fitorreguladores tem o objetivo principal de suprir as possíveis deficiências dos teores endógenos de hormônios nos explantes que se encontram isolados das regiões produtoras na planta-matriz. Porém, segundo estes autores, nem sempre é benéfica a aplicação de fitorreguladores imediatamente após o isolamento do explante da planta-matriz, pois eles podem estimular respostas indesejáveis, como a formação de calo e, eventualmente, intoxicar os tecidos. Jaakola et al. [11] verificaram que a adição de auxina ao meio de cultura, no estabelecimento in vitro de Vaccinium myrtillus, estimulou a calogênese, ou então, o escurecimento e morte dos explantes (segmentos nodais). Segundo estes autores, nenhuma regeneração ocorreu a partir destes calos, a não ser quando os mesmos foram transferidos para um meio de cultura sem fitorreguladores de crescimento ou para um meio contendo apenas citocininas.

Por outro lado, a adição exclusiva do fitorregulador de crescimento $2 \mathrm{iP}$ ao meio de cultura mostrou-se indispensável para a maximização do estabelecimento in vitro neste experimento (com $70,74 \%$ de estabelecimento) (Tabela 1), o que corrobora a afirmativa de Grattapaglia e Machado [9], de que a adição de citocininas é favorável ou, até necessária, para a iniciação e estabelecimento in vitro das culturas.

\section{Experimento II}

Da mesma forma que o observado no experimento I com a cv. Flórida, a contaminação e a oxidação dos explantes não se mostraram como problemas sérios ao estabelecimento in vitro de mirtilo cv. Delite, o que se deve, provavelmente, à manutenção das plantas-matrizes em ambiente limpo e protegido (casa de vegetação) e à pulverização prévia das mesmas com antibiótico e fungicidas. A contaminação bacteriana e a contaminação fúngica ocorreram, em média, em $0,96 \%$ e $7,26 \%$ dos explantes, respectivamente.

A oxidação foi nula nos explantes cultivados em meio semi-sólido, independentemente do comprimento dos explantes. No meio líquido, esta variou de zero (nula) a $13,46 \%$, conforme o comprimento dos explantes (Tabela 2). Este resultado vai de encontro à afirmativa de Blake [1], de que o meio líquido poderia diluir substâncias inibitórias ao desenvolvimento dos explantes in vitro. Por outro lado, resultados semelhantes aos observados neste experimento foram verificados no cultivo in vitro de segmentos de ráquilas de coqueiro anão [12], e de segmentos de ráquilas de açaizeiro [13], onde a maior percentagem de oxidação também ocorreu nos explantes cultivados em meio líquido. 
ERIG, A.C. e SCHUCH, M.W. Estabelecimento in vitro de mirtilo...

TABELA 2 - Percentagem de oxidação aos 21 dias de cultivo in vitro, e percentagem de sobrevivência aos 35 dias de cultivo in vitro, de explantes (segmentos nodais) de mirtilo cv. Delite, em função do comprimento do explante e do estado físico do meio de cultura. UFPel, Pelotas, RS. 2005.

\begin{tabular}{|c|c|c|c|c|}
\hline \multirow{2}{*}{$\begin{array}{l}\text { Comprimento do } \\
\text { explante }(\mathrm{cm})\end{array}$} & \multicolumn{2}{|c|}{ \% de oxidação* } & \multicolumn{2}{|c|}{ \% de sobrevivência* } \\
\hline & semi-sólido & líquido & semi-sólido & líquido \\
\hline 0,5 & $0,0 \mathrm{aB}$ & $13,46 a A$ & $97,19 a A$ & $70,74 \mathrm{bB}$ \\
\hline 1,0 & $0,0 \mathrm{aB}$ & $10,96 a A$ & $99,27 a A$ & $77,53 \mathrm{bB}$ \\
\hline 1,5 & $0,0 \mathrm{aA}$ & $0,0 \mathrm{bA}$ & $99,28 \mathrm{aA}$ & $100,0 \mathrm{aA}$ \\
\hline Média & \multicolumn{2}{|c|}{4,07} & \multicolumn{2}{|c|}{90,66} \\
\hline CV (\%) & \multicolumn{2}{|c|}{99,34} & \multicolumn{2}{|c|}{12,73} \\
\hline
\end{tabular}

*Médias não seguidas pelas mesmas letras, minúsculas na coluna e maiúsculas na linha, diferem pelo teste de Duncan em nível de $5 \%$ de probabilidade de erro.

A sobrevivência dos explantes cultivados em meio semi-sólido foi superior à obtida em meio líquido, com exceção para o segmento nodal de $1,5 \mathrm{~cm}$ de comprimento, que não diferiu estatisticamente (Tabela 2). Mesmo a percentagem de sobrevivência dos explantes cultivados em meio líquido sendo elevada (variando de $70,74 \%$ a $100 \%$ ) (Tabela 2), a percentagem de estabelecimento, nesta condição, foi praticamente nula $(0,74 \%)$ (Tabela 3$)$. Este resultado reforça a afirmativa de Erig e Schuch [5], citada anteriormente.

TABELA 3 - Percentagem de estabelecimento de explantes (segmentos nodais) de mirtilo cv. Delite, aos 35 dias de cultivo in vitro, em função do estado físico do meio de cultura. UFPel, Pelotas, RS. 2005.

\begin{tabular}{lc}
\hline \multicolumn{1}{c}{ Estado físico do meio de cultura } & $\%$ de estabelecimento* \\
\hline semi-sólido & $79,23 \mathrm{a}$ \\
líquido & $0,74 \mathrm{~b}$ \\
\hline Média & 39,98 \\
CV $(\%)$ & 41,63 \\
\hline
\end{tabular}

*Médias não seguidas pelas mesmas letras diferem pelo teste de Duncan em nível de 5\% de probabilidade de erro.

Por outro lado, a alta percentagem de sobrevivência no meio semi-sólido (acima de 97\%) também propiciou uma alta percentagem de estabelecimento $(79,23 \%)$ (Tabela 3$)$. No estabelecimento in vitro de mirtilo usando segmentos nodais, Popowich e Filipenya [20], obtiveram com a cv. Herbert, $90,9 \%$ de sobrevivência dos explantes e $40 \%$ de estabelecimento, utilizando meio WPM semi-sólido suplementado com 2iP. Grattapaglia e Machado [9] mencionam que meios semi-sólidos são comumente utilizados na fase de isolamento, embora em alguns casos sejam usados meios líquidos, como mostram os trabalhos de Gupta et al. [10] e de Skene e Barlass [25], com segmentos nodais de eucalipto e ápices de videira, respectivamente.

\section{CONCLUSÕES}

A adição de 24,6 $\mu \mathrm{M}$ de 2iP ao meio de cultura WPM favorece o estabelecimento in vitro de mirtilo cv. Flórida.

$\mathrm{O}$ estabelecimento in vitro de mirtilo cv. Delite é favorecido com o uso de meio de cultura semi-sólido, e não é influenciado pelo comprimento do explante.

\section{AGRADECIMENTOS}

Ao Ministério da Ciência e Tecnologia (MCT) / Conselho Nacional de Desenvolvimento Científico e Tecnológico (CNPq); e A Fundação de Amparo à Pesquisa do Estado do Rio Grande do Sul (FAPERGS).

\section{REFERÊNCIAS}

1. BLAKE, J. Tissue culture propagation of coconut, date and oil palm. In: DOODS, J.H. (ed.). Tissue culture of trees. London: Croom Helm, 1983. p.23-50.

2. CASTILLO, A.; CARRAU, J.S.F.; LEONI, C.; PEREIRA, G. Investigación en arandanos en Uruguay: propagación in vitro y evaluación de variedades por INIA. In: SIMPÓSIO NACIONAL DO MORANGO, 2.; ENCONTRO DE PEQUENAS FRUTAS E FRUTAS NATIVAS, 1., 2004, Pelotas, RS. Palestras e Resumos... Pelotas: Embrapa Clima Temperado, 2004. p.225-228. (Documentos 124). 
ERIG, A.C. e SCHUCH, M.W. Estabelecimento in vitro de mirtilo...

3. CORREAA, E.R.; FRAZON, R.C.; TREVISAN, R.; GONÇALVES, E.D.; RASEIRA, M.C.B. Germinação in vitro, do pólen de diferentes cultivares de mirtilo. In: SIMPÓSIO NACIONALDO MORANGO, 2; ENCONTRO DE PEQUENAS FRUTAS E FRUTAS NATIVAS, 1., 2004, Pelotas. Palestras e Resumos... Pelotas, RS: Embrapa Clima Temperado, 2004. p.145-148. (Documentos 124).

4. DONADIO, L.C.; NACHTIGAL, J.C.; SACRAMENTO, C.K. Frutas exóticas. Jaboticabal: Funep. 1998. 279p.

5. ERIG, A.C.; SCHUCH, M.W. Tipo de explante e controle da contaminação e oxidação no estabelecimento in vitro de plantas de macieira (Malus domestica Borkh.) cvs. Galaxy, Maxigala e Mastergala. Revista Brasileira de Agrociência, Pelotas, v.9, n.3, p.221-227, 2003.

6. FACHINELLO, J.C.; HOFFMANN, A.; NACHTIGAL, J.C.; KERSTEN, E.; FORTES, G.R.L. Propagação de plantas frutíferas de clima temperado. 2.ed., Pelotas: Editora UFPel, 1995. 179p.

7. GAMBORG, O.L.; MILLER, R.A.; OJIMA, K. Nutrient requirement of suspension cultures of soybean root cells. Experimental Cell Research, New York, v.50, p.151-158, 1968.

8. GONZALES, M.V.; LOPEZ, M.; VALDES, A.E.; ORDAS, R.J. Micropropagation of three berry fruit species using nodal segments from field-grown plants. Annals of Applied Biology, Cambridge, v.137, p.73-78, 2000.

9. GRATTAPAGLIA, D.; MACHADO, M.A. Micropropagação. In: TORRES, A.C. et al. Cultura de tecidos e transformação genética de plantas. Brasília: Embrapa-SPI / Embrapa-CNPH, 1998. v.1, p.183-260.

10. GUPTA, P.K.; MASCARENHAS, A.F.; JÁGANNATHAN, V. Tissue culture of forest trees-lonal propagation of mature trees of Eucalyptus citriodora Hook, by tissue culture. Plant Science Letters, Amsterdam, v.20, p.195-201, 1981.

11. JAAKOLA, L.; TOLVANEN, A.; LAINE, K.; HOHTOLA, A. Effect of $\mathrm{N}^{6}$-isopentenyladenine concentration on growth initiation in vitro and rooting of bilberry and lingonberry microshoots. Plant Cell, Tissue and Organ Culture, Hague, v.66, p.73-77, 2001.

12. LEDO, A.S.; GOMES, K.K.P.; VIEIRA, G.S.S. Estabelecimento inicial de segmentos de ráquilas de coqueiro anão em diferentes condições de cultura in vitro. In: CONGRESSO BRASILEIRO DE FRUTICULTURA, 18., 2004, Florianópolis. Anais... Florianópolis, SC: SBF, 2004. 4p.

13. LEDO, A.S.; LAMEIRA, O.A.; BENBADIS, K.A.; MENEZES, I.C.; OLIVEIRA, M.S.P.; LEDO, C.A. Avaliação da oxidação de segmentos de ráquilas de açaizeiro (Euterpe oleracea Mart.) sob diferentes condições de cultura in vitro. Revista Ciências Agrárias do Pará, Belém, n.35, p.9-14, 2001.

14. LLOYD, G; McCOWN, B. Commercially feasible micropropagation of mountain laurel (Kalmia latifolia) by use of shoot-tip culture. Proceedings of the International Plant Propagation Society, v.30, p.421-427, 1980.

15. MAINLAND, C.M. Propagation and planting. In: ECK, P.; CHILDERS, N.F. Blueberry culture. New Brunswick: Rutgers University, 1966. p.111-131.

16. MONTARROYOS, A.V.V. Contaminação in vitro. ABCTP Notícias, Brasília, n.36 e 37, p.5-10, 2000.

17. MONTEIRO, C. La expansion de la producción de arandanos en Uruguay y su relación con el Hemisferio sur. In: SIMPÓSIO NACIONAL DO MORANGO, 2; ENCONTRO DE PEQUENAS FRUTAS E FRUTAS NATIVAS, 1., 2004, Pelotas. Palestras e Resumos... Pelotas, RS: Embrapa Clima Temperado, 2004. p.233-241. (Documentos 124).

18. MURASHIGE, T.; SKOOG, F. A revised medium for rapid growth and biossay with tobacco tissue cultures. Physiologia Plantarum, Copenhagen, v.15, p.473-497, 1962

19. PAGOT, E.; HOFFMANN, A. Produção de pequenas frutas no Brasil. In: SEMINÁRIO BRASILEIRO SOBRE PEQUENAS FRUTAS, 1., 2003, Vacaria, RS. Anais... Bento Gonçalves: Embrapa Uva e Vinho, 2003. p.9-17. (Documentos 37).

20. POPOWICH, E.A.; FILIPENYA, V.L. Effect of exogenous cytokinin on viability of Vaccinium corymbosum explants in vitro. Russian Journal of Plant Physiology, New York, v.44, n.1, p.90-93, 1997.

21. SANTOS, A.M. Situação e perspectivas do mirtilo no Brasil. In: SIMPÓSIO NACIONAL DO MORANGO, 2; ENCONTRO DE PEQUENAS FRUTAS E FRUTAS NATIVAS, 1., 2004, Pelotas. Palestras e Resumos... Pelotas, RS: Embrapa Clima Temperado, 2004. p.281-284. (Documentos 124).

22. SANTOS, A.M.; RASEIRA, M.C.B. A cultura do mirtilo. Pelotas: Embrapa Clima Temperado, 2002. 30p.

23. SHARPE, R.H. Consultant's Report. Pelotas: IICA/Embrapa - UEPAE de Cascata, 1980. 11p.

24. SILVA, L.C.; SCHUCH, M.W.; SOUZA, J.A.; ANTUNES, L.E.C. Efeito do local de coleta e desinfestação de explantes no estabelecimento in vitro de cultivares de mirtilo (Vaccinium spp.). In: CONGRESSO BRASILEIRO DE FRUTICULTURA, 18., 2004, Florianópolis. Anais... Florianópolis, SC: SBF, 2004. 4p.

25. SKENE, K.G.M.; BARLASS, M. Micropropagation of grapevine. Proceedings of the International Plant Propagation Society, v.30, p.564-570, 1980.

26. ZONTA, E.P.; MACHADO, A.A. SANEST - Sistema de análise estatística para microcomputadores. Registrado na SEI Secretaria Especial de Informática, sob nº66.060, Categoria A. Pelotas, 1984. 